\title{
THE POLICY OF SOVIETIZATION OF THE WESTERN REGIONS OF UKRAINE IN 1944 - 1953 THROUGH THE PROPAGANDIST SYMBOLS AND RITUALS
}

\author{
Galyna STARODUBETS - Ruslana POPP
}

\author{
Zhytomyr Ivan Franko State University \\ Department of the World History \\ Velyka Berdychivska 40 \\ 10008 Zhytomyr \\ Ukraine \\ starodubec@gmail.com \\ ORCID ID: 0000-0003-2005-771X \\ WOS Researcher ID: M-9514-2015 \\ Ivan Franko Drohobych State Pedagogical University \\ Department of the Ukraine History \\ Ivan Franko 24, \\ 82100 Drohobych \\ Ukraine \\ ryslana_popp@ukr.net \\ ORCID ID: 0000-0002-5370-1770 \\ WOS Researcher ID: F-9496-2018
}

STARODUBEC, Galyna - POPP, Ruslana. The Policy Of Sovietization Of The Western Regions Of Ukraine In The Postwar Period Through The Propagandist Symbols And Rituals. In Studia Historica Nitriensia, 2020, vol. 24, no. 2, pp. 412-427, ISSN 1338-7219, DOI: 10.17846/SHN.2020.24.2.412-426. The article deals with the peculiarities of the process of Sovietization of the western regions of Ukraine in the first postwar years. The problem of using the political symbols as tools of propaganda by the authorities is particularly emphasized. The scientific novelty is that the process of symbolizing the living space of the population of the Western Ukrainian region in the period of restoration / establishment of Soviet power there is disclosed in the article. The authors indicate what The main promoters of the spread of "Soviet" were the propaganda and agitation departments of regional and district committees of the $\mathrm{CP}(\mathrm{b}) \mathrm{U}$ in Western Ukraine. The change of symbolic space occurred through the creation and implantation into the public consciousness of a new narrative of the historical uniqueness of the Soviet state of the Stalinist format.

STARODUBEC, Galyna - POPP, Ruslana. Politika sovietizácie západných oblastí Ukrajiny v povojnovom období cez prizmu propagandistických symbolov a rituálov. In Studia Historica Nitriensia, 2020, roč. 24, č. 2, s. 412-427, ISSN 1338-7219, DOI: 10.17846/SHN.2020.24.2.412-426.

Článok sa zaoberá osobitost'ami procesu sovietizácie západných oblastí Ukrajiny v prvých povojnových rokoch. Osobitný dôraz sa kladie na problém využívania politických symbolov ako nástro- 
jov propagandy orgánmi moci. Vedecká aktuálnost' spočíva v tom, že sa odhal'uje proces symbolizácie životného priestoru obyvatel'ov západoukrajinského regiónu v období obnovy / založenia sovietskej moci. Autorky poukazujú na to, že hlavnými propagátormi šírenia "sovietov“ boli propagandistické a agitačné oddelenia západoukrajinských oblastných a okresných výborov KP(b)U (Komunistickej strany (bol'ševikov) Ukrajiny). Zmena symbolického priestoru nastala vytvorením a aplikovaním nového naratívu o historickej jedinečnosti sovietskeho štátu stalinistického formátu do verejného povedomia.

Kl'účové slová: západné oblasti Ukrajiny; sovietizácia; propagandistické symboly a atribúty; masmédiá; verejné udalosti;

Keywords: Western Regions of Ukraine; Sovietization; Propaganda Symbols and Attributes; Mass Media; Public Events;

One of the most important tasks of any government that seeks to establish its control in a certain territory is its legitimization, which means that citizens/population recognize it as justified and legal. Historical experience shows that real power cannot be invoked solely by force. The effectiveness of its functioning depends not only on material factors but also, what is more important, on ideological ones, which lie in the sphere of spiritual life of people. The restoration of state institutions of Soviet power in the western regions of Ukraine immediately after the liberation of these territories from the Nazi occupation regime did not mean that the local population recognized its legitimacy. This is clearly demonstrated by the large-scale national liberation movement. The process of Sovietization determined it's strengthening in 1944.

The anti-Soviet resistance movement was represented not only as an open armed struggle, but also as a latent confrontation on the level of the public consciousness. That is why the Bolshevik authorities were tasked with reformatting its matrix by using the powerful arsenal of the Bolshevik propaganda machine. In conditions of the unfolding of complicated process of Sovietization of the region, the replacement and filling its symbolic space with its new ideological content were considered as one of the tools of the political and propaganda campaign.

Nowadays, when the European political space in general and Ukraine in particular are in turbulence determined by the unfolding of information wars, the topic of constructing and filling in the meanings of new political symbols becomes relevant.

In contemporary historiography the topic of using the symbols, rituals and images by political elites in order to consolidate the society, create the social and cultural environment to support national/political identity has been reflected in various scientific fields: philosophical, legal, historical, political and so on. The problems of symbolic politics and representation of power through symbols are widely covered in the works of foreign and domestic researchers, in particular, O. Malinova ${ }^{1}$, S. Potseluev ${ }^{2}$,

1 MALYNOVA, Olga. Symbolic Policy: outlines of problematic field. In Symbolic Policy: Constructing of images about the past as a power resource, 2012, no. 1, pp. 5-16.

2 POTSELUYEV, Serhey. "Symbolic Policy": On History of the Concept. In Symbolic Policy: Constructing of images about the past as a power resource, 2012, no. 1, pp. 17-53. 
Y. Krasnokutska ${ }^{3}$, S. Denysiuk ${ }^{4}$ and others. The researchers of political science define symbolic capital" as one of the important "resources of winning and retention of political power, accompanied by the legitimization of the new order and the delegitimization of the old political institutions" ${ }^{5}$; as "a powerful tool with the help of which we construct political reality" ${ }^{6}$. An English researcher of social science D. Thompson believes that authorities use "symbolic forms to be able to interfere with events or influence people" 7 . German researchers S. Urbansky and F. Askermann, define "the constructing of the Soviet space through changes in the visual and linguistic environment" as one of the most important instruments of the Sovietization of the newly annexed territories.

In the contemporary domestic scientific discourse the problem of symbolization the political space of the Western Ukrainian region in terms of its Sovietization still has not become the subject of a thorough scientific analysis of the researchers of history. Some of its aspects are covered in the works of T. Marusyk ${ }^{9}$, B. Yarosh ${ }^{10}$, Y. Levina ${ }^{11}$, V. Mishchanyn ${ }^{12}$, O. Dokash ${ }^{13}$, R. Popp ${ }^{14}$, G. Starodubets ${ }^{15}, \mathrm{~V}$. Trofymovych ${ }^{16}$ and others. The vast majority of the authors

3 KRASNOKUTSKA, Yuliya. Mass Media and Symbolic Policy: the aspects of influence. In Contemporary Society: political sciences, social sciences, cultural sciences, 2012, no.1, pp. 14-19.

4 DENYSIUK, Svitlana. Symbol as a Form of Political Communication. In State and Law, 2012, no. 55, pp. 544-550.

5 POLIANSKA, Viktoriya. Symbolic Policy: essence, structure, conditions of implementation. In Political Management, 2004, no. 3, p. 92.

6 KERTZER, David. Ritual, Politics, and Power. New Haven; London: Yale University Press, 1988, p. 75.

7 THOMPSON, John. Ideology and Modern Culture. Critical Social Theory in the Era of Mass Communication. Oxford: Polity Press, 1990, p. 56.

8 URBANSKY, Sören - ACKERMANN, Felix. Einleitung - Introduction: Reframing Postwar Sovietization. Power, Conflict, and Accommodation. Jahrbücher für Geschichte Osteuropas, 2016, vol. 64, no. 3, p. 359.

9 MARUSYK, Tamara. The West-Ukrainian arts intelligentsia: life realia and its activities (40-50-ies of the 20th century). Chernivtsi: Ruta, 2002, 463 p.

10 YAROSH, Bogdan. Totalitarian regime in west-Ukrainian lands in 1930 - 1950 (a historicalpolitological aspect). Lutsk: Nadstyrria, 1995, 176 p.

11 LEVINA, Yulia. The information and outreach policy of the soviet government during the election period in the western regions of the Ukssr in 1939-1941. In Scientific Issues Ternopil Volodymyr Hnatiuk National Pedagogical University. Series: History, 2014, no. 2, pp. 48-54.

12 MISCHANYN, Vasyl. Ideological intervention of Communist party in the activity of the creative intellectuals of Transcarpathia (1946-1950). Scientific Corpus of the University of Uzhgorod. Series: Philology. Social Communications. 2011, no. 25, pp. 105-110.

13 DOKASH, Oksana. Strengthening of the ideological control of stalinist totalitarian regime over politics and cultural space of western regions of the Ukrainian SSR (late 40's - early 50th century). In State and law, 2016, no. 73, pp. 51-60.

14 POPP, Ruslana. Ideological-propaganda policy of the soviet system in the western regions of Ukraine in 1944 - 1953 (according to the materials of Drohobych region). In East European historical bulletin, 2018, no.8, pp. 143-152.

15 STARODUBETS, Galyna. The missionaries of the Red power (Soviet Party Nomenclature of the Western Regions of Ukraine in 1944-the Beginning of 1946). Zhytomyr:"Polissya", 2016, pp. 87-142.

16 TROFYMOVYC, Volodymyr - KUTSKA, Olesia. Special propaganda of the Soviet Union at the end of the second world war in scientific late XX - early XXI century. In Military-historical meridian: electronic scientific journal, 2017, no 4. pp. 26-41. 
agree that the political and ideological work of the Bolshevik Party was an integral part of the process of Sovietization. It aimed, first of all "to achieve the state unification of cultural and aesthetic criteria of society"17, to restructure the symbolic space of the Western Ukrainian region, to fill it with the new meanings, while allowing "no deviation from Soviet ideological standards"18. Changing the visual and linguistic environment gradually, the Stalinists imposed on society of Western Ukrainian region the Bolshevik system of moral values and norms. The researchers emphasize that "the active participation of the intelligentsia in the implementation of propaganda tasks became a special Soviet feature"19. In addition to party-soviet officials, local activists, representatives of journalistic communities and the "humanitarian intelligentsia" were the subjects of political and propaganda work ${ }^{20}$. Since the topic of symbolization of the living space of the population of the Western Ukrainian region during the period of restoration/ establishment of Soviet power is still poorly researched, the object of our scientific analysis is the political and propaganda sphere of activities of local regional committees of the Communist Party (Bolsheviks) of Ukraine $(\mathrm{CP}(\mathrm{b}) \mathrm{U})$, focusing on the ways and methods of creation and spreading the narrative of the historical uniqueness of the Soviet state of the Stalinist format. The purpose of our article is to investigate the meaningful filling of the arsenal of political symbols and rituals used by Bolshevik propaganda in the process of Sovietization of the western regions of Ukraine in 1944-1946.

Despite the powerful levers of militaristic pressure on the local population, the Bolsheviks also actively used various tools of propaganda nature to "spread their ideological and political beliefs to the audience in order to form views, values, impressions, emotions, ideology and to influence the human and social behavior" 21 . It should be emphasized that the leaders of the Bolshevik Party have traditionally drawn the enormous attention to the agitation and propaganda work, the content and forms of which were accurately regulated and controlled by the relevant party bodies. In particular, to lead all the ideological party work in March 1939, the Central Committee of the Central Committee of the All-Union Communist Party (bolsheviks) established a propaganda and agitation department, which was divided into 5 departments in its structure: party propaganda, Marxist-Leninist personnel training, press, agitation and cultural and educational institutions ${ }^{22}$.

17 DOKASH, ref. 13, p. 55.

18 BARAN, Volodymyr - TOKARSKYI, Vasyl. "Zachistka": Political Repression in the Western Regions of Ukraine in 1939 - 1941. Lviv: Institute of Ukrainian Studies. I. Krypiakevych NANU, 2014, 456 p.

19 POCHEPTSOV, George. Propaganda 2.0. Kharkov: Folio, 2018, p. 524.

20 MARUSYK, ref. 9.; DOKASH, Oksana. Mentality of the population of the western regions of Ukraine as an object of political, cultural and ideological influence of the Stalinist totalitarian regime (late 30's - early 50's of XX century. Internet project "Ukrainian Mentality: Linguistic, Literary, Historical, Cultural and Political and Legal Dimensions", April 17-18, 2016 [Online]. Available on the internet: http: // mentalnist-2016.blogspot.com/p/blogpage_12.html.

${ }^{21}$ DANILIN, Pavel. Political Propaganda: New Technologies. [Online]. Evailable on the internet: http:/ / www.evartist.narod.ru/text28/0001.htm

22 NEVEZHIN, Volodimir. "If campaign starts tomorrow...." Preparation to War and Ideological Propaganda in 30s - 40s. Moscow: Yauza, Eksmo, 2007, p. 55. 
The same structure unit was established by the Central Committee of the $\mathrm{CP}(\mathrm{b})$ $\mathrm{U}$ and the relevant departments - in all regional committees of the Bolshevik Party. Their main task was to form the ideological basis of the Bolshevik-Soviet political system by applying a set of "propaganda symbolic instruments to control everything: physical space, informational space and, of course, virtual space" 23 . By that time, the "nomenclature" of political symbols and rituals had already been formed in the ideological arsenal of the regime. Those symbols and rituals have already undergone some sort of testing during the formation of the command-administrative system and proved to be effective. The victorious ending of World War II generally strengthened the Soviet Union's position on the world stage and, as a consequence, contributed to even greater sacralization of the image of Stalin - the "chief of all times and peoples" and "the Soviet political system" with all its attributes.

After several years of break, the Bolshevik authorities returned to Western Ukrainian region. On the one hand, it was confronted with the openly hostile attitude of the local population towards everything that represented it. On the other hand, it faced the large-scale anti-Soviet propaganda launched by the insurgent underground and the Ukrainian Insurgent Army (Ukrayinska Povstanska Armiya, UPA). That is why it was extremely important for the Bolsheviks "to gain control over public conversations about the pre-Soviet past, the post-war present and the Soviet mission of building a modern future" 24 . This could be achieved through the "constructing, erasing of a memory", first of all, by the tools of mass propaganda, deep-rooted moral and ethical norms and values of the Western Ukrainian society, and planting instead fundamentally other moral standards and social norms. One of the most important methods of achieving such goal was the creation of an extensive network of mass media, first of all, newspapers, cultural and educational institutions, organization of symbolic ersatz-events with the participation of representatives of local Committees of the $\mathrm{CP}(\mathrm{b}) \mathrm{U}$ and bodies of Soviet power, such as: gathering of workers, peasants, meetings and demonstrations to use them as channels to broadcast the ideological foundations of the Bolshevik-Soviet power.

Total propaganda under the Stalinist regime "became possible with the help of the control of the party/state over all mass media and other social institutions which influence the way people think" ${ }^{\prime 25}$. An extremely important role in the process of establishing the Stalin regime was granted to the press. Therefore, the restoration and adjustment of the work of print publishing houses was one of the first steps by the Soviet authorities after the liberation of the Ukrainian territories from the German occupiers. "In 1944, five publishing houses were already active in Ukraine: Ukrderzhvydav, "Soviet School", Silgospvydav, by the Academy of Sciences of the Ukrainian Soviet Socialist Republic (USSR) and by the Union of Soviet Writers of Ukraine. Since 1944, these publishing houses pub-

${ }_{23}$ POCHEPTSOV, ref. 19, p. 525.

24 URBANSKY - ACKERMANN, ref. 8, p. 359.

25 DOKASH, Oksana. Political and cultural transformation of western regions of Ukraine in the context of establishing the ideology of Soviet totalitarianism (1930's - 1950's). Manuscript, 2017, p. 228. 
lished 696 books and brochures with a total circulation of 16 million 677 thousand copies, much of which was intended for the western regions of the USSR" ${ }^{26}$. The same practice spread to the western regions of Ukraine, as well. Thus, "the first issue of the Drohobych regional newspaper "Soviet Word" was published on August 12, 1944 with a circulation of 3000. By September 25 it was planned to increase the circulation to $10000^{\prime 27}$. By the beginning of $1945 \mathrm{n}$ Stanislav region "14 newspapers had already been organized. One of them is a regional newspaper with a circulation of 15 thousand copies, town one in Kolomyia and 12 district newspapers" ${ }^{28}$, in Ternopil region - 30, one of which is regional, 27 - district and 2 - town" 29 .

Since there were no alternative press editions, the regional and district newspapers as the body of local Committees of the $\mathrm{CP}(\mathrm{b}) \mathrm{U}$, became not only an instrument of party propaganda, but also one of the political symbols and attributes of the new power. In the first weeks after the arrival of Soviet power, under conditions when it was not possible to resume the work of district newspapers because of the "poverty of the printing base, especially fonts" 30 , "because of complete lack of editorial staff, ....... in some districts of Drohobych region the district committees issued a postcard "From the Soviet information bureau" (Sambir, Stryi, Khodoriv, Rudky, Zhydachiv, Mostyska, etc.) and spread throughout the villages" 31 . "In the Ternopil region with a lack of newspapers, literature, qualified agitation and propaganda staff - most of the Soviet and party assets went to villages every Sunday for talks" ${ }^{\prime 2}$. The topics and content of newspaper articles as well as the public speeches of party agitators and propagandists were never of spontaneous nature but were accurately regulated by the relevant guidance documents of the regional and district committees of the $\mathrm{CP}(\mathrm{b}) \mathrm{U}$.

The regional party-Soviet leadership was tasked with "achieving the fastest transformation of the western regions of Ukraine in the regions with all kinds of development of the Soviet economy and culture by imposing the people with our Soviet worldview, Soviet understanding, our Soviet culture, knowledge of our Soviet laws" ${ }^{\prime \prime}$. It is worth noting the fact of using the dichotomy "their-ours" with

26 MALIARCHUK, Oleg. Totalitarianism against Western Ukrainian village. Ivano-Frankivsk: Misto NV, 2008, p. 92-93.

27 Central State Archives of Public Organizations of Ukraine (hereinafter referred to as TsDAGO of Ukraine), fund 1 the Central Committee of the Communist Party of Ukraine, distr. 70, file 207 (Reports on the state of agitation, propaganda, cultural and educational work in Drogobych, Ternopil and Poltava regions), p. 35.

28 TsDAGO of Ukraine, fund 1, distr. 70, file 301 (The transcript of the Third Republican Meeting on Propaganda and Agitation at the Central Committee of the CP (b)U), p. 167.

29 TsDAGO of Ukraine, fund 1, distr. 70, file 207 (Reports on the state of agitation, propaganda, cultural and educational work in Drogobych, Ternopil and Poltava regions), p. 35.

30 TsDAGO of Ukraine, fund 1, distr. 70, file 301 (The transcript of the Third Republican Meeting on Propaganda and Agitation at the Central Committee of the CP (b)U, p. 167.

31 TsDAGO of Ukraine, fund 1, distr. 70, file 207 (Reports on the state of agitation, propaganda, cultural and educational work in Drogobych, Ternopil and Poltava regions), p. 35.

32 TsDAGO of Ukraine, fund 1, distr. 70, file 207 (Reports on the state of agitation, propaganda, cultural and educational work in Drogobych, Ternopil and Poltava regions), p. 29.

33 TsDAGO of Ukraine, fund 1, distr. 70, file 359 (The transcript of an inter-regional meeting of editors of regional and city newspapers in the western regions of the Ukrainian SSR on elimination 
"ours" as Soviet, progressive and "theirs" is another, hostile, the one that poses a threat to the current political system. Using a well-established set of propaganda clichés, political rituals, the authorities constructed a new symbolic space with no room for an authentic, nationally-oriented segment of social life.

The analysis of the topics of newspaper publications, lectures of the party-Soviet agitators allows us to distinguish several components from a wide range of key symbols which served as markers for the designation of "Sovietness". First of all, this is the image of the chief Stalin who was associated with all the progressive changes in the country, above all, with the victory in World War II (in particular, the obligatory acquaintance with the text of his book "On the Great Patriotic War of the Soviet Union"; popularization of the topic "Lenin and Stalin and their role in the history of the Ukrainian people", etc. ${ }^{34}$. The focus of the political propaganda was also placed on the topic "Rights and Responsibilities of Soviet Citizens stated in the Stalin's Constitution" with emphasize on the Communist Party's care about the working masses of the Soviet Union ${ }^{35}$. Starting from 1945, both the columns of regional newspapers and speeches of various agitators and propagandists from the party were overflowing with the topic of collective farm construction. The image of the collective farm and the farmer as the representative of the prosperous Soviet village is being actively and obsessively shaped: "The collective farm is the way to a prosperous life", "Kurkuli - the evil enemies of the working peasantry"36, etc.

In the process of the propaganda campaign regarding collectivization of agriculture in the western regions of Ukraine, the authorities widely used manipulative technologies which "are manifested in the ability of propaganda in the process of its implementation to camouflage itself as information which is not always noticed by the objects of propaganda" ${ }^{37}$. Thus, the columns in newspapers, the speeches of officials often used the figures which should have testified the mass and voluntary nature of the establishment of collective farms in Western Ukrainian villages. The illusion of popular support for the Bolshevik Party policies was created by organizing meetings. The local peasants obligatory had to make the speeches expressing their admiration for the collective farm system. Their performances emotionally charged a listening audience which has generally passive, "it made possible to translate the officially provided information from the field of rational perception into a purely emotional and psychological one ${ }^{\prime \prime 38}$.

the remnants of German fascist agents - Ukrainian nationalists), p. 2.

34 TsDAGO of Ukraine, fund 1, distr. 70, file 427 (Reports, references, plans of work on the implementation by a group of consultants of $\mathrm{CC} C P(b) U$ decisions of of $C C \mathrm{CP}(b) \mathrm{U}$ on measures to strengthen political and ideological work in the western regions and the Donbas.), p. 15.

35 TsDAGO of Ukraine, fund 1, distr. 70, file 1026 (Reports on the work of propaganda and agitation departments of Rivne, Stalin, Stanislav, Sumy and Ternopil regional committees of the $\mathrm{CP}(\mathrm{b}) \mathrm{U})$, p. 132.

36 TsDAGO of Ukraine, fund 1, distr. 70, file 277 (Reference reports on the work of political and educational institutions in the western regions of Ukraine), p. 31.

37 HULAY, Vasil. Inmutation vector of stalinist totalitarian regime advocacy communicative impact on the residents of the Western Ukraine (winter 1944 - spring 1945). In Military scientific journal, 2015, no. 23, p. 60.

38 KOSTIANTIN, Nikitenko. Reaction of the Soviet culture and art on the signing of the MolotovRibbentrop Pact: official propaganda and the truth of history). In Bulletin Lviv National Acad- 
Since mid-1940s, the pages of regional newspapers have been overflowing with information that "the peasant farms, having seen the benefits of the collective farm system, are merged into collective farms" ${ }^{\prime 39}$. Speeches of the most successful collective farmers in front of the peasant audience, trips of delegations of peasants of the western regions of Ukraine to the collective farms of the Eastern Ukrainian region were widely practiced. For example, at the beginning of 1945 "10 women of the Lubomyl district in Volyn region were sent to the best collective farm in Poltava region". Their trip was widely advertised on the pages of the district newspaper "in order to educate the work of the best collective farms, which will help us in collectivization process, - as the editor-in-chief noted" ${ }^{\prime 0}$. Such speeches by agitators "from the people" served as a kind of tool used by the authorities to paint gray-black background in the positive colors during such unpopular state event as the collectivization of the village. War heroes, production leaders, Stakhanovtsi, rationalizers, mothers of many children, deputies, athletes, and Komsomol activists were positioned as symbols of the era, of the new advanced Soviet life. The stories about them were traditional in all press publications of the time. Their importance and influence were visualized by photos in elegant attire (often in Ukrainian vyshyvankas) on the front pages of newspapers, "Honor Boards" - at the places where the other peasants, family, friends and neighbors could see them.

The process of Sovietization included not only the introduction of new Sovietstyle institutions, but also "key elements such as changes in the visual and linguistic environment" ${ }^{\prime 1}$. Opposite the symbols with positive connotation the authorities modelled and aggressively imposed images with the negative content. All those who were openly opposed to the Stalinist regime or were its potential enemy according to the Bolsheviks assumptions, were clichéd as "UkrainianGerman bourgeois nationalists", which was later replaced by "Banderivtsi". They were accused of cooperating and serving the German occupiers and the "exploiters of the working people". The conceptual design of the image of the members of the Ukrainian national liberation movement as "bandits" was based on a famous report by D. Manuilskyi at an inter-regional meeting of an asset of teachers of western regions of Ukraine in January 1945 - "Ukrainian-German Nationalists in Service in Nazi Germany", which was published in all newspapers, there was even a brochure published basing on it ${ }^{42}$. Immediately after that, in all Western Ukrainian press editions with relevant content and loud titles appear: "Independence freezes", "Uproot the last fascist bastards", "Ways of falling

emy of Arts, 2015, no. 27, p. 14.

39 State archive of Rivne region, fund P-400 (Rivne regional party committee), distr. 1, file 97 (The transcript of the second regional meeting of women of the Rivne region), p. 94.

40 TsDAGO of Ukraine, fund 1, distr. 70, file 359 (The transcript of an inter-regional meeting of editors of regional and city newspapers in the western regions of the Ukrainian SSR on elimination the remnants of German fascist agents - Ukrainian nationalists), p. 98.

41 URBANSKY - ACKERMANN, ref. 8, p. 357.

42 MANUILSKYI, Dmytro. Ukrainian-German Nationalists in Service of Nazi Germany: Report on January 6, 1945, at a Meeting of Teachers from the Western Regions of Ukraine. Kiev: Ukrainian State Publishing House, 1946, 24 p. 
and betrayals"43. It is worth emphasizing that they were diverse in genres - from the official articles on the front pages to satirical sketches, "letters and claims" of the workers. The vast majority of published articles did not rely on real facts. However, the methodical production of a large number of such publications has raised doubts among the local population and has exacerbated social conflicts. In its toxic propaganda, the communist authorities quite consciously put a sign of equality between the Ukrainian national liberation movement and the Nazi occupation regime, trying to build a stable associative link, articulated in an eclectic definition, full of negative semantic connotations - "Ukrainian-German bourgeois nationalists".

The collective image of the "banderivets" implanted by the Soviet authorities into the public space of the western regions of Ukraine was used as a propaganda tool to enhance the status of the "Soviet hero". A contemporary researcher G. Pocheptsov calls this tool - "enemy management" and states that "propaganda both, in the past and nowadays realizes the management of the enemies in a strategy to demonize (make negative) the enemy, who begins to perform the actions for which he should be destroyed. Enemy management forces the mass consciousness to justify any action against those who have been branded as an enemy"44. This kind of demonic image of the enemy as an antithesis to the positive symbols of Soviet power, Bolshevik propaganda designed around the figure of the "Ukrainian insurgent", "nationalist underground".

In order to increase the emotional impact on the local population, the Bolshevik propagandists widely used such a method as a public claiming to their countrymen of the former members of the rebel underground and the UPA, who confessed their guilt and repented openly. In this aspect we can put as a bright example the story-confession of M. I. Artemovych, a resident of the village Dorozhiv, published in the newspaper "Soviet Word" in March 1946 entitled "Shame and death to cursed traitor" 45 . According to the classics of the genre, the author explicitly renounces his past by condemning his previous activities in the first part of the article. M. Artemovych had a rich biography: once he was a village and volost viyt-, so "the servant of the nobility", "Polish authorities". He was also linked by extraordinary family relationships (his sister's husband was Dmytro Hrytsay "Perebyinis"). Trying to prove his loyalty to the Soviet authorities, M. Artemovych emphasizes that with the appearing of Soviet troops, he voluntarily joined the ranks of the Red Army, served as a sapper, reached Berlin, was awarded certificates and medals. At the same time, his daughter and son were fighting in the UPA (at the time of publication, the son was killed in a confrontation with the representatives of NKVD and the daughter continued the resistance). Actually, the father's appeal to his daughter to leave the ranks of bandits - banderivtsi became the background for the publication of the following official claim of the Presidium of the Supreme Soviet of the Ukrainian SSR, the

\footnotetext{
43 Soviet word, 1. 2. 1946, p. 1, Independence freezes; 6. 3. 1946, p. 4, Uproot the last fascist bastards; 22. 9. 1946, p. 4, Ways of falling and betrayals.

44 POCHEPTSOV, George. From Pokémon to Hybrid Wars: New Communication Technologies of the 21st Century. Kiev: Publishing house "Kyiv-Mohyla Academy”, 2017, p. 51.

45 Soviet word, 5. 3.1946, p. 4, Shame and death for the cursed traitors.
} 
Soviet People's Commissar of the Ukrainian SSR and the Central Committee of the $\mathrm{CP}(\mathrm{b}) \mathrm{U}$ to the participants of the independent movement to surrender ${ }^{46}$. The similar articles can be found on the pages of newspapers of other regions. For example, in autumn of 1945, the regional newspaper of Stanislavshchyna published "a letter from a former participant of OUN who worked as teacher. He was in the Halych district in the district administration. He tells in detail how he was recruited into the gang and how he became convinced that the participants of OUN are the servants of fascism" ${ }^{\prime 4}$. At the initiative of local party officials, the text of this letter was circulated in settlements whose residents knew the man.

The launching of a mass campaign to discredit national memory sites, displacing both, spiritual and material commemorative practices from the living space of Western Ukrainians was another widespread method of imposing new political symbols. In this framework we can illustrate the resolution of the Military Council of the 4th Ukrainian Front as of September 12, 1944, which stated that "the hirelings of Hitler robbers - Ukrainian fascists banderivtsi and melnykivtsi, built mounds (in the form of graves with a cross) in large settlements as signs of solidarity with the fascists who occupied the Soviet Ukraine in 1941. There is an image of the fascist sign of participants of OUN - the Tryzub (tridents), as well as inscriptions "To fighters for the freedom of Ukraine" on the crosses" 48 . Therefore, it was decreed: "crosses, tryzubs and inscriptions should be removed. Do not destroy mounds, but put pyramids on them - monuments with a red star" 49 . It was clearly stated that "a sickle and hammer should be attached to the road or town on the left side; the following inscription in Ukrainian should be obligatory: "Eternal glory to the Red Army soldiers who perished from the German invaders for Soviet Ukraine". On the other sides of the mound there should be inscriptions: "Death to the German invaders and their hirelings, let Soviet Ukraine live". The representatives of the local party-soviet nomenclature were obliged to organize the ceremonial opening of new memorials in of the massive presence of local residents. Making speeches in Ukrainian was an obligatory attribute of this kind of events. The main content of the speeches were following topics: heroism of the Red Army in the struggle for the liberation of the Ukrainian people from German slavery; exposing and cursing the representatives of OUN as German spies and enemies of the Ukrainian people and the Red Army ${ }^{50}$. It should be noted that in

46 Soviet word, 5. 3. 1946, p. 4, Shame and death for the cursed traitors.

47 TsDAGO of Ukraine, fund 1, distr. 70, file 301(The transcript of the Third Republican Meeting on Propaganda and Agitation at the Central Committee of the CP (b)U), p. 171.

48 State archive of Lviv region (hereinafter referred to as SALR), fund P-5001 (Drohobych regional party committee), distr. 1, file 51(Correspondence with the Central Committee of $\mathrm{CP}(\mathrm{b}) \mathrm{U}$ ) and additional notes on the political mass and propaganda work among the workers of the region on the state of the printing infrastructure, the work of the radio station, the editorial staff of the Soviet word newspaper), p. 13.

49 SALR, fund P-5001, distr. 1, file 51 (Correspondence with the Central Committee of $\mathrm{CP}(\mathrm{b}) \mathrm{U}$ ) and additional notes on the political mass and propaganda work among the workers of the region on the state of the printing infrastructure, the work of the radio station, the editorial staff of the Soviet word newspaper), p. 13.

50 SALR, fund P-5001, distr. 1, file 51 (Correspondence with the Central Committee of CP (b)U)and additional notes on the political mass and propaganda work among the workers of the region 
the postwar years, the practice of establishing of various monuments to Soviet soldiers, who died in the battles with the Germans and had to symbolize the victory of the Soviet Army over fascism, became widespread. At the same time, the graves of Ukrainian rebels were erased from the ground, their burial places were plowed and so on.

Radio broadcasting was another powerful tool for the spread of political propaganda in the post-war period. Its' broadcasts simultaneously reached a large audience and were accessible to the audience. Its importance for the Soviet authorities is evidenced by the fact that the topic of radiography of settlements in Western Ukraine was the subject of discussion on November 1, 1945 at a meeting with the Deputy Head of the propaganda and agitation department of the Central Committee of the $\mathrm{CP}(\mathrm{b}) \mathrm{U}$. The responsible officials for the organization of propaganda work in the regional committees of the Party of Western Ukrainian regions attended the meeting. Regional party functionaries emphasized that "previously the western regions did not have the same radiography as they do now. The people are not used to this, so they install the radio connection with no great desire, finding the excuse in lack of funds" ${ }^{\prime 1}$. Nevertheless, the need for as soon as possible installation of radio broadcasting in the Western Ukrainian region was emphasized. Such attention was caused by the launch of an agitation and propaganda campaign for the elections to the Supreme Soviet of the USSR in February 1946.

The meaning of radio messages did not differ from the content of articles in periodicals and had a purely ideological and propaganda nature. The dominant topics were: struggle against national movement, heroism of the Soviet Army, positive activities of the authorities in the field of education, medicine, culture, economic reconstruction, collectivization, Soviet elections, historical and national-cultural unity of the Ukrainian and Russian peoples and international events. "The progressiveness" of everything of Soviet nature was demonstrated on the background of the "baring" of the previous authorities and regimes. The general trust of the population of the region in radio information is evidenced by the fact that it (radio) was called "liar" ("brekhunets") at the household level ${ }^{52}$. Nevertheless, radio was gradually becoming a necessary attribute of the everyday life of the Soviet person.

The Soviet political symbols were planted not only through the media, but also through public events which served as the part of post-war everyday life. Meetings, gatherings, lectures, political information firmly and for a long time became part of the Soviet everyday life, being transferred into ritual activities. Their target audience included both, general and with specific orientation, for example professional, social, national: teachers, doctors, intelligentsia, workers, peasants, women, militaries, repatriates, etc. The organization and holding these public

on the state of the printing infrastructure, the work of the radio station, the editorial staff of the Soviet word newspaper), p. 13.

51 TsDAGO of Ukraine, fund 1, distr. 70, file 350 (The transcript of the meeting on the implementation of decisions of the Central Committee of the $\mathrm{CP}(\mathrm{b}) \mathrm{U}$ on campaigning among the population of the western regions of Ukraine), p. 16.

52 VURLOVS'KA, Mariia. Radio in everyday life of the inhabitants of Drohobych land (1944 1958). In East European historical bulletin, 2018, no. 6, p. 201. 
events during the period we defined was under the precise control of the district committees and regional committees of the $\mathrm{CP}(\mathrm{b}) \mathrm{U}$. The efficiency of the work of party agitators and propagandists was usually determined by quantitative indicators. Therefore, each report necessarily included both, the number of meetings or gatherings held and the scale of the audience of the event. It is clear that local officials have tried to maximize this figure. For example, the propaganda and agitation department of Drohobych regional committee counted 1223 lectures conducted in September-October 1944 and the party leadership claimed that there were many more, because "the gatherings were held not only once or twice" 53 in the villages; In September 1945, the functionaries of the Ternopil region reported on "conducting of 1724 reports and lectures, holding 2347 individual and group conversations with a coverage of 66773 people" 54 .

The scenarios of the gatherings and meetings were similar. As a rule, the representatives of the authorities made the speeches firstly. Their reports were confirmed by district and towns regional committees of the $\mathrm{CP}(\mathrm{b}) \mathrm{U}$ in advance. Speeches by local representatives in which they declared their support for the Bolshevik Party's policies were obligatory part of these meetings. At the end, they collectively wrote letters of appeal to Union and Republic party state leaders ${ }^{55}$.

Despite all the efforts of local authorities, Western Ukrainian society resisted the planting of new symbols and drawing them into various ritual activities of political nature. Gatherings and meetings organized by party officials, as a rule, provoked irritation of the local population and forced them to passive resistance. The reports of the participants of the Ukrainian national underground of that time contain much information that "the village population does not attend the Bolshevik gatherings to not meet the Bolsheviks", "the gatherings in the villages do not work, people do not go, but rather run away",... "the Bolsheviks wanted to conduct a gathering in the village of Dmytrovychi, they detained people near the church but the people ran away, there was no gathering",... "the further from the district, the worse was the agitation" 56 . For example, in Pustomytivskyi district, "general participation is insignificant, driven by force" ${ }^{57}$; in Yavorivskyi district "agitation is completely weakened. Gatherings are not arranged because no one attends" ${ }^{\prime \prime 8}$. It is emphasized that the militaries were often involved in organizing

53 SALR, fund P-5001, distr. 1, file 51 (Correspondence with the Central CP (b)U) and additional notes on the political mass and propaganda work among the workers of the region on the state of the printing infrastructure, the work of the radio station, the editorial staff of the Soviet word newspaper), p. 20.

54 TsDAGO of Ukraine, fund 1, distr. 70, file 207 (Reports on the state of agitation, propaganda, cultural and educational work in Drogobych, Ternopil and Poltava regions), p. 29.

55 SALR, fund P-5001, distr. 6, file 33 (Transcript of the Intelligentsia Meeting on the 27th Anniversary of the Great October Socialist Revolution and on the Tasks of the Soviet Intelligentsia and on the Role of the Intelligentsia in Fighting the Ukrainian Bourgeois Nationalists), p. 20-205.

56 Sectoral State Archive of Security Service of Ukraine (hereinafter referred to as HDA SBU), fund 13 (Collection of printed periodicals of the USSR KGB), distr. 376 (OUN's documents and materials of reporting and informational nature for 1943-1952), part 76, p. 72.

57 HDA SBU, fund 13, distr. 376 (OUN's documents and materials of reporting and informational nature for 1943-1952), part 76, p. 34.

58 HDA SBU, fund 13, distr. 376 (OUN's documents and materials of reporting and informational nature for 1943-1952), part 76, p. 59. 
and conducting the events ${ }^{59}$. The conclusions of the Ukrainian underground often overlap with those of the party authorities of the time. Thus, local officials in Drohobych district state in their reports that "when teachers and doctors hold the gatherings, they hold these meetings very apolitically ... not a word was mentioned about nationalists" ${ }^{60}$. Similar thoughts are found in an official letter from the functionaries of the Volyn regional committee to the department of propaganda and agitation of the Central Committee of the $\mathrm{CP}(\mathrm{b}) \mathrm{U}$, where it is stated that "in a number of districts the agitation mass work is carried out in campaign style" 61 .

The technique of Soviet propaganda to use the mass public events which "should demonstrate (directly or indirectly) the popular support of the authorities by the people - as G. Pocheptsov correctly points out, - has been known since antiquity" ${ }^{\prime \prime 2}$. However, the Stalinist regime brought this practice to a certain absolute point, a mandatory norm for every Soviet citizen whose political loyalty was evidenced by following this norm. Gradually, the gatherings became ritual activities with a clear scenarios, which are associated in the public consciousness with the Soviet authorities. Moreover, demonstration of the active/passive position of the participants of the gathering served as a kind of marker of division of the population into "ours" / "enemies".

The expulsion of the Nazi occupiers from the western regions of Ukraine did not mean that the Soviet system had taken control of the situation in the region. The process of legitimization of power, the "conquest" of the population was in sharp force and ideological propaganda confrontation with the Ukrainian liberation movement.

The main promoters of the spread of "Soviet" were the departments of propaganda and agitation of the Western regional committees, town committees and district committees of the $\mathrm{CP}(\mathrm{b}) \mathrm{U}$ represented by their leaders and employees. The change of symbolic space took place through the creation and implantation into the public consciousness of a new narrative of the historical uniqueness of the Soviet state of the Stalinist format, which was denied by all authentic, national-oriented ones. Through mass media (newspapers, magazines, radio broadcasting) and public events (gatherings, meetings, lectures, political information), a positive image of the government and its policies in all spheres (restoration, collectivization, education, culture, medicine, social protection, democratic rights) was imposed.

Since the new "present" and "future" required a new understanding of the "past", the Bolshevik ideologists directed their efforts to reformat the "past" of the Western Ukrainian region. The dominant associative images of the Soviet system were "Stalin - the chief of the working people", "party official", "Great October Revolution", "collective farmer", "Stakhanovets", etc. In contrast to symbols with

\footnotetext{
59 HDA SBU, fund 13, distr. 376 (OUN's documents and materials of reporting and informational nature for 1943-1952), part 76, p. 80.

60 POPP, ref. 14, p. 147.

61 TsDAGO of Ukraine, fund 1, distr. 70, file 1014 (The report of the Volyn Regional Committee of the $\mathrm{CP}(\mathrm{b}) \mathrm{U}$ on the work of the propaganda and agitation department for the first half of 1947), p. 44.

62 POCHEPTSOV, ref. 44, p. 524.
} 
a positive connotation, the authorities modeled and aggressively imposed images filled with negative content. These include, first and foremost, the figure of a Ukrainian underground rebel, branded with emotionally charged ideological clichés such as "Ukrainian-German bourgeois nationalist", "Banderivets" and others. It is significant that the authorities demanded from the population of the region not only a passive acceptance of the Soviet symbols, but also a public demonstration of a positive attitude towards them. It was one of the markers of the division of Soviet citizens into "ours" and "enemies". As a result of such a policy we have the gradual demarcation of Ukraine into "Western Banderivtsi" and "Easterners", the conscious incitement of inter-regional enmity. Ukraine is still experiencing its phantom pain.

\section{Literature and sources:}

\section{Archive sources:}

Central State Archives of Public Organizations of Ukraine (hereinafter referred to as TsDAGO of Ukraine), fund 1 the Central Committee of the Communist Party of Ukraine, distr. 70.

Sectoral State Archive of Security Service of Ukraine (hereinafter referred to as HDA SBU), fund 13 (Collection of printed periodicals of the USSR KGB), distr. 376 (OUN's documents and materials of reporting and informational nature for 1943-1952), part 76.

State archive of Lviv region (hereinafter referred to as SALR), fund P-5001 (Drohobych regional party committee), distr. 1.

State archive of Rivne region, fund P-400 (Rivne regional party committee), distr. 1, file 97 (The transcript of the second regional meeting of women of the Rivne region).

\section{Press:}

Soviet word, 1946.

\section{Monographs:}

BARAN, Volodymyr - TOKARSKYI, Vasyl. "Zachistka": Political Repression in the Western Regions of Ukraine in 1939-1941. Lviv: Institute of Ukrainian Studies. I. Krypiakevych NANU, 2014.

KERTZER, David. Ritual, Politics, and Power. New Haven; London: Yale University Press, 1988.

MALIARCHUK Oleg. Totalitarianism against Western Ukrainian village. Ivano-Frankivsk: Misto NV, 2008.

MANUILSKYI, Dmytro. Ukrainian-German Nationalists in Service of Nazi Germany: Report on January 6, 1945, at a Meeting of Teachers from the Western Regions of Ukraine. Kiev: Ukrainian State Publishing House, 1946.

MARUSYK, Tamara. The West-Ukrainian arts intelligentsia: life realia and its activities (40-50-ies of the 20th century) Chernivtsi: Ruta, 2002.

NEVEZHIN, Volodimir. "If campaign starts tomorrow... " Preparation to War and Ideological Propaganda in 30s - 40s. Moscow: Yauza, Eksmo, 2007.

POCHEPTSOV, George. From Pokémon to Hybrid Wars: New Communication Technologies of the 21st Century. Kiev: Publishing house "Kyiv-Mohyla Academy", 2017.

POCHEPTSOV, George. Propaganda 2.0 . Kharkov: Folio, 2018.

STARODUBETS, Galyna. The missionaries of the Red power (Soviet Party Nomenclature of the Western Regions of Ukraine in 1944-the Beginning of 1946). Zhytomyr:"Polissya", 2016.

THOMPSON, John. Ideology and Modern Culture. Critical Social Theory in the Era of Mass Communication. Oxford: Polity Press, 1990.

YAROSH, Bogdan. Totalitarian regime in west-Ukrainian lands in 1930 - 1950 (a historical-politological aspect). Lutsk: Nadstyrria, 1995. 


\section{Articles:}

DENYSIUK, Svitlana. Symbol as a Form of Political Communication. In State and Law, 2012, no. 55, pp. 544-550.

DOKASH, Oksana. Strengthening of the ideological control of stalinist totalitarian regime over politics and cultural space of western regions of the Ukrainian SSR (late 40's - early 50th century). In State and law, 2016, no. 73, pp. 51-60.

HULAY, Vasil. Inmutation vector of stalinist totalitarian regime advocacy communicative impact on the residents of the Western Ukraine (winter 1944 - spring 1945). In Military scientific journal, 2015, no.23, pp. 57-68.

KOSTIANTIN, Nikitenko. Reaction of the Soviet culture and art on the signing of the Molotov-Ribbentrop Pact: official propaganda and the truth of history). In Bulletin Lviv National Academy of Arts, 2015, no. 27, pp. 4-16.

KRASNOKUTSKA, Yuliya. Mass Media and Symbolic Policy: the aspects of influence. In Contemporary Society: political sciences, social sciences, cultural sciences, 2012, no. 1, pp. 14-19.

LEVINA, Yulia. The information and outreach policy of the Soviet government during the election period in the western regions of the Ukssr in 1939-1941. In Scientific Issues Ternopil Volodymyr Hnatiuk National Pedagogical University. Series: History, 2014, no. 2, pp. 48-54.

MALYNOVA, Olga. Symbolic Policy: outlines of problematic field. In Symbolic Policy: Constructing of images about the past as a power resource, 2012, no. 1, pp. 5-16.

MISCHANYN, Vasyl. Ideological intervention of Communist party in the activity of the creative intellectuals of Transcarpathia (1946-1950). Scientific Corpus of the University of Uzhgorod. Series: Philology. Social Communications. 2011, no. 25, pp. 105-110.

POLIANSKA, Viktoriya. Symbolic Policy: essence, structure, conditions of implementation. In Political Management, 2004, no. 3, pp. 87-97.

POPP Ruslana. Ideological-propaganda policy of the soviet system in the western regions of Ukraine in 1944 - 1953 (according to the materials of Drohobych region). In East European historical bulletin, 2018, no. 8, pp. 143-152.

POTSELUYEV, Serhey. "Symbolic Policy": On History of the Concept. In Symbolic Policy: Constructing of images about the past as a power resource, 2012, no. 1, pp. 17-53.

TROFYMOVYC, Volodymyr - KUTSKA, Olesia. Special propaganda of the Soviet Union at the end of the second world war in scientific late XX - early XXI century. In Military-historical meridian: electronic scientific journal, 2017, no. 4. pp. 26-41.

URBANSKY, Sören - ACKERMANN, Felix. Einleitung - Introduction: Reframing Postwar Sovietization. Power, Conflict, and Accommodation. Jahrbücher für Geschichte Osteuropas, 2016, vol. 64, no. 3, pp. 353-362.

VURLOVS'KA, Mariia. Radio in everyday life of the inhabitants of Drohobych land (1944 - 1958). In East European historical bulletin, 2018, no. 6, pp. 197-202.

\section{Internet sources:}

DOKASH, Oksana. Mentality of the population of the western regions of Ukraine as an object of political, cultural and ideological influence of the Stalinist totalitarian regime (late 30`s - early 50's of XX century). Internet project "Ukrainian Mentality: Linguistic, Literary, Historical, Cultural and Political and Legal Dimensions", April 17-18, 2016 [Online]. Evailable on the internet: http: // mentalnist-2016.blogspot.com/p/blogpage_12.html.

DANILIN, Pavel. Political Propaganda: New Technologies. [Online]. Evailable on the internet: http:/ / www.evartist.narod.ru/text28/0001.htm

Word count: 7891

Number of characters, including spaces: 51936 